EESTI NSV TEADUSTE AKADEEMIA TOIMETISED 1953, II k., nr, 4 ИЗВЕСТИЯ АКАДЕМИИ НАУК ЭСТОНСКОЯ ССР 1953. ТОМ II, ㅅ 4

\title{
НЕКОТОРЫЕ ВОПРОСЫ ЭТНИЧЕСКОИ ИСТОРИИ НАРОДОВ СОВЕТСКОЙ ПРИБАЛТИКИ В СВЕТЕ НОВЫХ ЭТНОГРАФИЧЕСКИХ И АНТРОПОЛОГИЧЕСКИХ ДАННЫХ *
}

\author{
H. Н, ЧЕБОКСАРОВ,
}

доктор исторнческих наук

Балтийская этнографо-антропологическая экспедиция, начавшая свою полевую работу летом 1952 года, организована Институтом этнографии им. Миклухо-Маклая АН СССР совместно с Институтом истории и права АН Литовской ССР, Институтом этнографии и фольклора АН Латвийской ССР и Институтом истории и Этнографическим музеем АН Эстонской CCP.

В задачу экспедиции входит, в первую очередь, всестороннее антропологическое и этнографическое изучение народов Советской Прибалтики с целью выяснения их происхождения, дальнейшей этнической истории и характера культурных взаимоотношений с соседними народами, в особенности с русскими и белорусами. Одной из главных задач экспедиции являются также исследования процессов социалистического переустройства культуры и быта литовского, латышского и эстонского колхозного крестьянства. В настоящее время именно эта задача выдвигается на первый план и становится основной задачей всей советской этнографической науки, а следовательно и Балтийской экспедиции. Для народов Советской Прибалтики задача эта представляется особенно важной и актуальной, поскольку прибалтийские народы сравнительно недавно окончательно и бесповоротно вступили на путь социализма. Капитализм со всеми его «прелестямн», проявлявшимися также в области культуры и быта, для прибалтийских народов не далекое прошлое, которое стало уже забываться. Нет, это вчерашний день, прошлое совсем недавнее. На примере прибалтийских народов так же, как и на примере других народов, недавно вступивших в состав Советского Союза, можно с особой яркостью показать всю глубину изменений культуры и быта, пронсшедших в период строительства социализма и пронсходящих сейчас в период постепенного перехода от социализма к коммунизму.

Вплоть до весны 1940 года в странах Восточной Прибалтики Литве, Латвии и Эстонии - действовал основной закон современного капитализма, проявлявшийся чрезвычайно ярко во всех областях культуры и быта. В настоящее время в этих странах, как и во всем Советском Союзе, действует уже основной экономический закон социализма, кото-

* Доклад, прочитанный 14 февраля 1953 года на сессии Отделения исторических наук Академии наук СССР. (Печатается в сокращенном виде.) 
рый проявляется в области культуры и быта принципиально иначе. За очень короткий исторнческий промежуток произошли огромные сдвиги во всех сторонах культуры и быта прнбалтийских народов. Ясно, что этнографы, работающие нал изучением нстории народов Прибалтики, должны выявить эти изменения, показать, в какие конкретные формы они выливаются у прибалтийских народов.

Таким образом, задачи Балтийской экспедиции очень многообразны и в настоящей статье не могут быть освещены с исчерпывающей полно10й. В составе Балтийской экспедиции, как можно было вндеть из перечня учреждений, которые принимали участие в ее организащии, работало много исследователей различных специальностей. В 1952 году в экспедиции участвовало около 60 человек, главным образом этнографов и антропологов - преимущественно работников республиканских научных учреждений Прнбалтики, в меньшей степени - работников центральных этнографических научных учреждений Москвы и Ленинграда.

Антропологическим обследованием летом 1952 года в Прибалтике было охвачено 1845 человек взрослых мужчин в 18 местных группах литовцев, латышей и эстонцев, а также белорусов Сморгоньского района Молодечненской области БССР и русских Островского района Псковской области РСФСР. Не будем перечислять те группы, которые исследовались в отдельных Прибалтийских республиках. Подчеркнем только, что эти группы были выбраны с таким расчетом, чтобы получить материал по основным местным группировкам населения, обладающим определенными этнографическими, культурно-бытовыми, а в значительной степени и языковыми (диалектологическими) особенностями. Эти исторически сложившиеся местные группы населения в составе литовщев, латышей и эстонщев частично восходят к древним племенным делениям и в какой-то степени отражают существовавшие в древности племенные группы. Частично же эти местные группировки сложились в более позднее время, главным образом уже в средние века, в феодальную эпоху.

Этнографические работы в прошлом году проводились главным образом в восточных районах Советской Прибалтики, где с наибольшей яркостыю выражено экономическое и культурное взаимодействие между различными народами, в частности между прнбалтийскими народами и русскими. Такой выбор определялся, как легко видеть, основными задачами экспедиции, указанными выше. Лнтовский и латышский этнографические отряды работали на смежных территориях в Литве в Рокишкском, Панделисском и Обеляйском районах на севере республики, а в Латвии на юге - в Неретском и Акнистском районах. Это как раз районы, непосредственно примыкающие к только что указанным районам Литовской ССР. Маршрут работы трех групп эстонского этнографического отряда проходил вдоль границы Эстонской ССР н РСФСР через Вастселинаский и Кыхвиский районы Эстонии, Печорский и Качановский районы Псковской области.

Начнем анализ материалов, собранных Балтийской экспедицией, с антропологических данных. В свое время И. В. Сталин в своей работе «Марксизм и национальный вопрос» указывал, что все современные нащии сложились из людей различных рас и племен. Показать, из каких племен, в какое время, в какой исторической обстановке и в силу каких причин сложились современные нации и народы - это дело историков в широком смысле слова, включая археологов и этнографов, а также языковедов. Показать же, из каких рас, из каких антропологических типов сложились народы и как происходило формирование их антропологического состава, - это дело антропологов, и именно в этой части 
они могут внести ценный вклад в изучение происхождения народов и их дальнейшей этнической истории.

Для всех нас совершенно очевндно, что советская антропология не изучает физический тип того или иного народа лишь для того, чтобы сказать, что у него преобладает такая-то форма головы, такая-то длина тела и т. д. или какой-то оттенок цвета волос или глаз. Раскрывая антропологический состав изучаемых народов, советские антропологи стремятся оказать помощь историкам и языковедам, работающим над вопросами этногенеза (происхождения) народов СССР и зарубежных стран. Не останавливаясь на всех этапах научного анализа антропологического материала, подчеркнем лишь, что изучение географической изменчивости важнейших антропологических признаков у народов Советской Прибалтики дает возможность выделить в составе современного населения Литвы, Латвии и Әстонии три основных антропологнческих комплекса, известных в советской антропологической литературе под названием «восточнобалтийского», «западнобалтийского» и «северочерноморскогож (иначе ксеверопонтийского»).

Для восточнобалтийского комплекса характерно сочетание таких антропологических признаков, как светлая окраска волос и в особенности глаз, мягкие, но большей частью прямые волосы, умеренное развитие третичного волосяного покрова на лице и на теле, средняя или выше среднего горизонтальная профилировка лица, иными словами - небольшое выступание скул при более сильном выступании вперед средней части лица. Однако у представителей этого типа встречаются иногда н несколько уплощенные лица. Другие признаки этого комплекса - зна. чительное развитие складки верхнего века в области глаза, среднее по высоте переносье, частое наличие вогнутых спинок носа и т. д. Представители этого типа в Прибалтике большей частью люди среднего или выше среднего роста, обладающие умеренно короткой (брахикефальной) формой головы.

Нет ни малейшего сомнения, цто этот комплекс относится к европеоидным антропологическим типам. Но вместе с тем он носит на себе некоторый, иногда едва уловимый, но все-таки вполне реальный отпечаток монголондности, некоторый, едва заметный, но все-таки определенный монголоидный налет. Восточнобалтийский антропологический тип в Прибалтике наиболее распространен среди эстонцев, в особенности среди уроженщев восточной Эстонии и среди сету. Однако он входит также в состав латышей и литовцев, хотя и в меньшей доле, чем в состав эстонцев.

Второй антропологический тип, ясно выделяющийся в Прибалтике, - западнобалтийский. Он характеризуется ярко выраженными европеондными особенностями (перечислять их нет смысла) в сочетании с такими признаками, как высокий рост, крупные общие размеры тела, большие абсолютные величины горизонтальных диаметров головы, значительное развитие надбровья, сравнительно наклонный лоб и некоторые другие особенности, которые антропологи обычно называют признаками «матуризации» (мужественности) или массивности. Для этого комплекса, как й для предыдущего, также характерно преобладание светлых глаз и умеренно светлых волос.

Западнобалтийский комплекс, который также, несомненно, относится к европеондной группе антропологических типов, не носит, в отличие от восточнобалтийского комплекса, никаких признаков монголоидности. Этот западнобалтийский комплекс локализуется прежде всего (на том материале, который был собран экспедицией, конечно) в западных райо- 
нах Латвии, в Курземе. Часто встречается он также в западных районах Эстонии (в районе Пярну) и у берегов Балтийского моря в Литве - в Кретингском и Кельмеском районах Жемайтии.

Третий антропологический комплекс, который может быть выделен в Прибалтике в результате изучения географической изменчивости антропологических типов у современного населения, - северочерноморский (северопонтийский). Он также относится к европеоидным типам, но отличается от первых двух более темной пигментапией, более интенсивной окраской, главным образом волос (при светлых глазах). Нужно сказать, что различие в цвете волос между различными прибалтийскими народами очень значительно. Эстонцы оказываются наиболее светловолосыми, латыши несколько более темноволосы, у литовцев же пигментация волос наиболее интенснвна. Определенная тенденция к темноволосости сочетается у представителей северочерноморского антропологического типа с такими признаками, как прямой лоб, слабо развитое надбровье, относительно узкое овальное лицо и т. п. - вообще с признаками «тонкости» - нли, как говорят антропологи, «грацильности» - строения лицевого скелета. Этот антропологический тип нанболее ярко выражен в составе литовцев. Не следует, однако, думать, что он там является основным, или, тем более, единственным; можно только утверждать, что концентрация его у литовцев более значительна, чем у латышей и, 'особенно, у эстонцев, где он встречается очень редко, только как исключение. Интересно, что и в Литве этот антропологический комплекс сосредоточивается преимущественно в южных районах республики (Дзукня), как бы выклиниваясь к северу.

Конечно, выделение этих антропологических типов само по себе еще ничего не дает для постановки вопроса о происхождении народов Прибалтики, тем более для его разрешения. Однако, сопоставляя материалы, относящиеся к антропологическому составу современного населения, с материалами палеоантропологии, относящимися к типам населения предшествующих исторических эпох, начиная по возможности с нанболее древней, можно прийти к определенным научным результатам, важным для понимания истории формирования антропологического состава населения Советской Прибалтики. Если же мы выйдем за рамки антропологии, - а антрополог, когда он пытается подойти к. разрешению исторических проблем, обязан выйти за рамки одной лишь «своей» науки, - и привлечем материалы этнографии и языковедения, то и самые антропологические данные, относящиеся к составу современного населения Прибалтики, заговорят живым языком и помогут в разрешении сложных вопросов пронсхождения и этнической истории народов Советской Прибалтики.

Но раныше, чем перейти к этим вопросам, целесообразно остановиться на ближайших географических аналогиях, на ближайших параллелях выделенным антропологическим типам. Восточнобалтийский комплекс как бы обращен лицом на восток - от Балтики к Уралу. Среди различных народов севера Европейской части СССР, как финских по языку, так и восточнославянских, можно встретить в большом количестве представителей восточнобалтийского типа, широко распространенного от карел до коми, от поморов, живущих на берегах Белого моря, до русских Средней полосы. Восточнобалтийский тип входит также в состав белорусов, поляков и восточных групп немцев.

Западнобалтийский тип имеет мало аналогий за пределами Прибалтики и в этом отношенни является наиболее специфичным для данной территории. Группы с наиболее ярким выражением его особенностей локализуются как раз в пределах Советской Прибалтики. Некоторые 
аналогии этому типу можно проследить на южных берегах Балтийского моря, в северной Польше (в частности, у кашубов в низовьях Вислы), на востоке Германин, на Ютландском полуострове, в южной Швеции, а также в Финляндии, главным образом в ее юго-западных районах н на Аландских островах.

Что касается северочерноморского типа, то он кобращен лицом» на юr - от Балтийского моря к Черному и к бассейну Дуная. Различные более или менее близкие к нему варианты понтийской группы умеренно депигментированных европеондов (шатенов) - широко распространены среди южных великорусов, белорусов и украннцев Полесья, молдаван, румын, болгар, адыгейских народов Северного Кавказа.

Можно сказать, таким образом, что в формировании антропологического состава населения Литвы, Латвии и Эстонии принимали участие типы, связанные со всеми тремя основными «узлами» образования антропологических комплексов населения Восточной Европы в целом Прибалтнкой, Приуральем и Причерноморьем.

После этого небольшого экскурса в область параллелей антропологическим типам населения Прибалтики возвратимся к сопоставлению их с палеоантропологическими материалами. Остановимся, в первую очередь, на тех выводах, которые напрашиваются при сопоставлении данных о современном населении с данными палеоантропология. В этой связи важно отметить, что за последние годы по Прибалтике собран и отчасти обработан большой палеоантропологический материал, относящийся главным образом к Эстонской ССР, где на базе этого материала подготовлена кандидатская диссертащия научного сотрудника Института истории АН Эстонской ССР К. Ю. Марк. По другим прибалтийским республикам такая работа еще не проведена, но она начинается также в Латвии и Литве, что, конечно, следует всячески приветствовать и поддержать.

С учетом всех этих материалов можно считать в достаточной степени вероятным, что типы, принадлежащне к той же группе, что и современный восточнобалтийский тип, были характерны с глубокой древности, во всяком случае с неолитического периода для большинства угрофинских племен, обитавших на севере Европейской части СССР, между Уралом на востоке и Балтийским морем на западе. Эти европеоидные типы с некоторым монголоидным «налетом», который все усиливался по мере продвижения с запада на восток, повидимому, были основными антропологическими комплексами, входившими в состав этих племен, а позднее и народностей на всем протяжении их истории. Наличие восточнобалтийского типа в качестве одного из основных типов населения Прибалтики указывает на то, что в формировании народов Прибалтики (не только эстонщев, но и латышей и литовцев) принимали участие какне-то племенные группы восточного - вернее всего, уральского, а может быть, и зауральского пронсхождения. Самое формнрование восточнобалтийского антропологического типа трудно объяснить иначе, как процессом смешения европеондных и монголондных элементов. Надо еще отметить, что среди палеоантропологических материалов, найденных на территории Приєалтики, в частности в Эстонии, имеется указание на существование близкого антропологического типа в древние времена, уже в период неолита. Речь идет о черепе из Тамула (на юго-востоке Әстонии). Череп этот, относящийся к неолиту и найденный вместе с ямочно-зубчатой керамикой, при общем европеоидном облике обнаруживает некоторые признаки смешения с древними монголоидными элементами (уплощенное лищо, слабое выступание носа и др.). А в дальнейшем можно проследить, как удельный вес этого древнего восточнобалтийского типа в населении 
Прибалтики постепенно увеличивается и ареал его становится все более н более обширным.

Если говорить о западнобалтийском типе, то несомненны связи его с древнейшими антропологическими типами населения Восточной и Центральной Европы, существовавшими здесь еще в эпоху верхнего палеолита. Палеоантропологические материалы показывают, что европеондные массивные типы, начиная по крайней мере со второго тысячелетия до нашей эры, были среди населения Прибалтики преобладающими. Есть основания предполагать, что распространение их по этой территорни пронсходило с юга, вероятно из бассейна Внслы. Мы не знаем точно, когда впервые эти антропологические типы попали на территорию Прибалтики; вероятно, это было очень давно, скорее всего в мезолитинескую эпоху, когда пронсходило первоначальное освоение людьми лесного севера Европейской части СССР. Но мы хорошо знаем, что во втором тысячелетин до нашей эры удельный вес этих типов в населении Прибалтики значительно увеличился. Почти все черепа и костяки, найденные в могильниках со шнуровой керамикой и боевыми топорами, относящнмися ко второму тысячелетию до н. э., принадлежат к этим массивным европеоидным типам. Весьма возможно, что само их распространение в Прибалтике было связано с расселением древнебалтийских племен - предков современных литовцев и латышей. Племена эти распространялиєь, повидимому, с юга, из бассейна Вислы, а может быть и из еще более южных территорий; первоначально они жили в Прибалтике рядом с финскими племенами, предками эстонцев и ливов, а затем слились с ними. В процессе этого слияния к югу от Даугавы (Западной Двины) на первых порах возобладала балтийская речь, а к северу от нее - финская.

Что касается третьего антропологического типа, характерного для народов Прибалтики, - северочерноморского, то можно предположительно говорить о проникновении его в более позднее время. Среди древнейших черепов с территорин Прибалтики этот тип, во всяком случае, отсутствует. По материалам, которыми мы располагаем в настоящее время, можно считать, что он появляется на территории Литвы в первых веках нашей эры (черепа из погребений III-IV веков, описанные Жилинскисом и Масальскисом). С какими исторнческими процессами, зафиксированными архео-

логически, можно связать появление этого типа с юга - сказать в настоящее время трудно. Это вопрос, требующий дальнейшего исследования.

Таковы основные итоги антропологических работ Балтийской экспедиции в той части, в которой они помогают осветить проблемы происхождения и этнической истории народов Прибалтики.

Этнографическими отрядами Балтийской экспедиции собирался материал по различным сторонам культуры и быта. Однако в процессе работ экспедиции, в соответствии с ее задачами, было выделено нееколько основных ведущих тем в области изучения материальной культуры. Такими темами были: поселения, жилище и хозяйственные постройки и отчасти одежда. Большое внимание в работах экспедиции, в особенности в работе литовского этнографического отряда, было уделено также изучению семейных отношений и семейного быта как в прошлом, так и в настоящем. Кроме того, собирался материал по национальному составу населения тех районов Прибалтики, где развернулись этнографические работы, и по характеру взаимоотношений между различными национальностями в этих районах. Остановимся на работах этого рода несколько более подробно.

Қак уже упоминалось, Балтийская экспедиция работала преимущественно в восточных районах Прибалтики. Материалы, собранные экспедищией, позволяют значительно уточнить наше представление о нащио- 
нальном составе населения этих районов, в частности позволяют установить, что здесь имеется значительная, неупоминавшаяся или мало упоминавшаяся в нсточниках группа русского населения. В Обеляйском районе Литовंккой ССР процент русского населения доходит до 20, а на юге Латвии - до 25 (Акнистский район). В Эстонии - на юге Йыхвиского района - имеется чрезвычайно интересная в этнографическом, историческом и лингвиетическом отношении группа смешанного населения, сложившаяся в процессе взаимодействия русских с эстонщами. Группа эта, живущая главным образом в пределах Ийсакского сельсовета, была известна в свое время под названием «полуверцев». Теперь назва ние это уже не употребляется.

Раньше в науке господствовало преувеличенное представление об изолированности русского староверческого населения в Прибалтике, которое отличалось не только по религиозной принадлежности, но и по культуре и быту от соседнего литовского, латышского нли эстонского населения. В действительности же между русскими и народами Прибалтики уже в условиях царской России происходило взаимное общение и культурный обмен, а иногда заключались даже смешанные браки. От русских народы Прибалтики много заимствовали в области материальной и духовной культуры. Имели место, однако, и обратные явления. Есть основания предполагать, что русское население в Прибалтике древнее, чем думали до настоящего времени. В том, что русское населенне жнло здесь с XVII века, нет сомнений. Но, может быть, отдельные группы русских в Эстонии, Латвии и Литве восходят и к более древним временам (период Ливонских войн в XVI веке и даже эпоха Кневской Руси).

Интересные результаты дали исследования в смежных районах Литвы и Латвин, проводившиеся Балтийской экспедицией. На юге Неретского района Латвии обследована группа, которая относится к латышам, говорит по-латышски и в наши дни с полным основанием входит в латвийскую нацию, но которая еще недавно (в середине XIX века) говорила политовски и прнчисляла себя к литовцам. Экспедиционные материалы дают возможность проследить, в какне конкретные формы выливается хозяйственное, культурное и языковое взаимодействне близких по происхождению народов - латышей и литовщев - в местах их соприкосновения.

Материалы, собранные экспедицией, показывают также, как изменился характер национальных взаимоотношений в наше время. Хорошо известно, что в буржуазное время во всех трех прибалтийских республиках культивировался шовинизм, враждебное отношение к другим народам, в особенности к русскому народу, самое существование которого в Прибалтике замалчивалось. Только в советскую эпоху, когда взанмоотношения между народами строятся на основе свободного сотрудничества н когда одна и та же по содержанию социалистическая культура выявляется н различных национальных формах, стало вөзможным изжитие шовинизма, искусственной изоляции между русским и нерусским населением, ложного чувства национальной «неполноценности».

Материальная культура народов Прибалтики изучалась этнографическими отрядами Балтийской экспедиции как в плане использования данньіх, относящихся к ней, для освещения тех или иных вопросов этнической истории прибалтийских народов, так и в плане показа крупнейших изменений и сдвигов в области материальной культуры, пронсшедших в наше время.

В результате работ экспедиции удалось, например, значительно уточнить территории распространения в Прибалтике трех основных традиционных типов крестьянских жилищ, сложившихся еще в феодальную эпоху. Эти три традиционных типа: 1) жилая рига, характерная в прош- 
лом для всех эстонцев, а также для северных латышей, 2) изба с холодными сенями и русской печью, характерная для всего русского населения Прибалтики, а также для сету, для восточных латышей (особенно для латгальцев) и соседних с ними селов и для большей части восточных литовцев, и, наконец, 3) жилой дом с каминной кухней, находящейся в теплых сенях, широко распространенный в прошлом в западных районах Латвии (Курземе, Земгале) и в Жемайтии.

Интересно отметить, что анализ связи тех или иных форм жнлиша с различнымн социальными группами сельского населения в период капитализма помог установить, что некоторые из тех типов жилищ, которые считались раньше «этнически» традиционными, оказались местами связаны с определенными социальными группами крестьянства. Так, например, сравнительно позднее распространение в XIX веке дома с каминной кухней в районах работы экспедиции - в южной Латвии и в соседних районах Литвы - оказалось связано с зажиточной группой крестьянства, представители которой строили дома с такой каминной кухней, в то время как беднящкая часть крестьянства продолжала жить в более древних на данной территории избах восточнославянского типа с холодными сенями и русской печью. Прощесс этот прослеживается с очень большой яркостью и определенностью. Он показывает, в частности, что при анализе различных культурных явлений, часто используемых для' освещения вопросов этногенеза и этнической истории, необходимо прежде всего исследовать, с какими конкретными социально-экономическими условиями связано бытование того или иного явления. Каково происхождение дома с каминной кухней на западе Литвы и Латвии, мы пока еще не знаем, но и этот вопрос, во всяком случае, следует изучить, отказываясь от распространенной в буржуазной литературе точки зрения, что этот тип дома заимствован откуда-то из Германии.

Материалы, собранные Балтийской экспедицией по жилищу, также помогают выявить те конкретные формы, в которых пронсходило экономическое и культурное взаимодействие народов Прибалтики и соседнего восточнославянского (русского и белорусского) населения. Несомненно, что именно от восточных славян народы Прибалтики получили жилой дом с холодными сенями и избой с русской печью, широко распространенный у сету, латгальцев и восточных литовцев. При изучении русско-эстонских смешанных групп Причудья удалось установить, как этот тип восточнославянского жилища комбинируется с традищионной эстонской жилой ригой, давая различные переходные формы, в которых под одной крышей сочетаются печь эстонского типа в риге, употреблявшаяся для сушки снопов, и русская печь в избе; между ригой и избой располагаются в домах такого типа холодные сени. Таким образом, эстонская «рехетуба» (жилая рига) сочетается с русской избой, называемой жистоба» (название «сени» остается и теперь для холодного коридора между ригой и избой). Это хороший пример того, как матерналы, собранные экспедицией в районах со смешанным населеннем, показывают, как складывается здесь своеобразная «переходная» материальная культура.

Не будем останавливаться подробно на результатах этнографического изучения поселений, одежды и других сторон материальной культуры. Отметим только, что и здесь удалось во многих случаях проследить различня между явлениями, связанными с этническими традициями, уходящими по крайней мере в феодальную эпоху, и более новыми явлениями, сложившимися в капиталистическую эпоху, которые выдавались буржуазными этнографами за этнически традиционные, что значительно затуманивало историю материальной культуры народов Прибалтики. Большое 
место, например, заняло в работах экспедиции разоблачение буржуазной легенды о специфической хуторской системе расселения латышей и об отсутствин у них деревень даже в древние времена. Как только экспедиңия приступила к. полевой работе, выяснилась вздорность этой легенды, десятилетиями культивировавшейся буржуазной лженаукой. Отдельные деревни у латышей существуют и в настоящее время, другие же прекратили свое существование совсем недавно в связи с насильственной политикой буржуазного правительства. Интересно, что буржуазное правительство Латвии нередко не только сознательно уничтожало эти деревни фактически, но и уничтожало их на бумаге, так сказать, фиктивно. Случалось, например, что реально существующие деревни безо всякого переселения пєереименовывались в хутора. Каждое хозяйство получало свое отдельное наименование и в списках населенных пунктов деревня числилась как совокупность хуторов.

Следует сказать еще несколько слов об изучении тех изменений и преобразований, которые в области материальной культуры пронсходят в Прибалтике в настоящее время и на которые Балтийская экспедиция также стремилась обращать внимание, изучать их по возможности широко и глубоко. Қак уже указывалось, совсем недавно в культуре и быте народов Прибалтики проявлялось действие основного экономического закона капитализма, сейчас же проявляется действие основного экономического закона социализма. В чрезвычайно короткий промежуток времени, буквально на наших глазах, здесь произошли крупнейшие сдвиги во всех сторонах культуры и быта.

Коллективизация, массовое вступление крестьян в колхозы развернулось в Прибалтийских республиках в 1949 году. В настоящее время коллективизация сельского хозяйства в основном закончена. В Прибалтике коллективизация пронсходила в своеобразных условиях преобладания хуторского расселения, - того самого хуторского расселения, о котором так много писали буржуазные авторы, изображая его как что-то специфическое для прибалтийских народов. Вне всякого сомнения, переход к коллективному хозяйству в условиях хуторского расселения создал ряд особых трудностей. С преодолением этих трудностей связаны многие спешифические изменения поселений, жилищ, частыю и других сторон матернальной культуры, наблюдаемые в Прнбалтике.

Одним из очень важных процессов, которые сейчас пронсходят во всей Прибалтике, является подготовка к сселению колхозников из хуторов в благоустроенные колхозныте поселки. Как мы хорошо знаем, - это процесс длительный. Он не может проводиться в административном порядке и в короткие сроки, но подготовка к нему уже ведется и занимает большое место в хозяйственной и обшественной жизни колхозников Прибалтийских республик. Здесь речь ндет, с одной стороны, о подготовке соответствуюших планов, типовых проектов как поселений в целом, так и отдельных жнлых построек, в обсуждении которых колхозники принимают очень деятельное участие. С другой стороны, речь идет уже и непосредственно o начале строительства. Әто строительство, как правило, захватывает первоначально постройки хозяйственного и общественного назначения. В быт прнбалтийского колхозного крестьянства, в его пронзводственную жизнь, уже вошел хозяйственный колхозный двор с его постройками коллективного пользования, не известными в индивидуальном крестьянском хозяйстве.

Как проходил процесс коллективизации в Прибалтике? Образовывались колхозы, объединившие хутора, разбросанные часто на огромной территории; при обобществлении инвентаря, скота н других средетв производства нужно было сосредоточить их в одном или, во всяком случае, в 
нескольких местах. И вот, стали создаваться бригадные дворы, за которыми закреглялась бо́льшая часть инвентаря, скота и т. д. Общеколхозные и бритадные дворы создавались большей частью на базе хозяйственных построек бывших наиболее крупных кулацких или помешичьих хозяйств. Так возникла своеобразная органнзация сельскохозяйственного труда в прибалтийских колхозах, сложились своеобразные взаимоотношения между колхозннкамн одной бригады. В состав такой бригады большей частью входят жители группы соседних дворов, в центре которых находится бригадный двор. Но это, конечно, переходная мера; вопрос о стронтельстве новых колхозных дворов остается в Прибалтике очень актуальным.

Для буржуазного периода истории Прибалтики характерна, как известно, резкая социальная дифференциация крестьянства. Эта дифференциация нашла свое отражение и в различных типах жилых построек: в Латвин, например, выработались своеобразные типы жилых построек зажиточных крестьян. Один из таких наиболее распространенных типов: в середине теплые сени, по одну сторону хозяйская половина, где жил хозяин с семьей, по другую же сторону батрацкая половина, где жили работники н работницы. Все в этих двух половинах было различно: в хозяйской - дощатый пол, разнообразная самодельная или покупная мебель, хорошие кровати, украшения на стенах; в батрацкой же - земляной пол, грубые лавки и столы, нары, голые закопченные стены. Нередки были в Эстонии и Латвии также кулацкие дома типа коттеджей; недалеко от них можно было видеть постройки в виде бани, где жили бобыли, работавшие на хозяев-кулаков. Здесь социальная дифференщиация типов жилищ выделялась еще более ярко.

И в наши дни жилой фонд, которым пользуются колхозники, в большинстве случаев старый; новые постройки уже создаются, но в основном колхозники живут в постройках старого типа. Тем не менее ксоциальные» типы жилищ уже не существуют, их больше нет, хотя стены их и остались старые. Бани, в которых раньше жили бобыли, очень редко используются как жилые постройки, они большей частью заколочены. Наиболее крупные коттеджи кулаков используются для различных общественных или культурных нужд. В других домах кулаков теперь живут новые люди, которые занимают совсем иное место в общественном пронзводстве, у которых другие потребности, другие быт и культура. Исчезло различие между хозяйской и батрацкой половинами. Помещения эти перестроены, приспособлены к новым потребностям семей колхозников, а не хозяев и батраков, как раньше.

Хозяйственные постройки на отдельных крестьянских усадьбах, в связи с переходом к коллективному хозяйству, сократились. Многие хозяйственные постройки, обслуживавшие отдельные крестьянские семьи, не используются нли используются совершенно по-новому. Так, например, в прошлом во дворах богатых или средних домохозяев часто были две клети, - одна для домашнего скарба, другая для хранения зерна. Сейчас эги клети используются отдельными колхозными семьями. В наши дни таких явлений очень много. Мы стремимся нх изучать. Будем изучать и в дальнейшем, так как они представляют очень большой ннтерес для этнографов как раз в плане решення задач, вставших перед нашей наукой в эпоху постепенного перехода от социализма к коммунизму.

На прибалтийском этнографическом материале полностью подтверждается положение о том, что при всех огромных преобразованиях в области культуры и быта, которые имеют место в наши дни, сохраняется, но прнобретает новые формы нащиональная спецнфнка различных народов нашей страны. Сами изменения, единые по своему содержанию для всех народов Советского Союза, проявляются у каждого из них в различ- 
ной национальной форме. Так, изучение одежды прибалтийских народов показывает, что в одежде этой и в наши дни много нащионально спещифичного. Так, например, разнообразные вязаные вещи, которые и сейчас вырабатываются латышами, литовцами и эстонцами, создаются в каждой республике по-разному. Нащиональная и местная специфика ясно сказывается в их покрое, отделке, орнаменте.

Антропологические и этнографические материалы, собранные Балтийской экспедищией, имеют также большое значение для разоблачения с фактами в руках буржуазно-националистической, в частности, расистской теории происхождения и истории культуры народов Прибалтики. Особенно велика в борьбе с этими течениями роль новых данных по этнической истории литовцев, латышей и эстонцев н по истории их культурных связей с русскими и другими народами Европейской части СССР. Матерналы экспедиции могут быть также использованы для разработки на конкретных данных по народам Прибалтики тех важнейших теоретических проблем в области изучения закономерностей развития этнических общностей в прошлом и настоящем, которые встали перед советской этнографической наукой в свете последних трудов И. В. Сталина и исторических решений XIX съезда Коммунистической партии.

Ннститут этнографии им. Н. Н. Миклухо-Маклая

Поступила в редакцию Академии наук Союза ССР

22 VII 1953 